\title{
Peran Lembaga Pengelola Perikanan (LPP) Dalam Perikanan Tuna Di Indonesia
}

\author{
Novita Yoseline Tambunan \\ Fakultas Hukum Universitas Indonesia \\ Email: novitaysln@yahoo.co.uk
}

\begin{abstract}
Abstrak. Ikan Tuna dengan daya jelajah luas melewati laut ZEE menjadi jenis ikan yang pengelolaannya menjadi tanggung jawab bersama antarnegara.Oleh karena itu, status pengelolaan perikanan tuna nasional selalu menjadi pantauan dari Lembaga Pengelolaan Perikanan Regional (Regional Fisheries Management Bodies - RFMOs). Kementerian Kelautan dan Perikanan belakangan ini mengeluarkan Peraturan Menteri Kelautan dan Perikanan Republik Indonesia No.33 Tahun 2019 tentang Organisasi dan Tata Kerja Lembaga Pengelola Perikanan di Wilayah Pengelolaan Perikanan Negara Republik Indonesia disusun dan ditetapkan untuk peningkatan efisiensi, optimalisasi, dan koordinasi pelaksanaan pengelolaan perikanan di Wilayah Pengelolaan Perikanan Negara Republik Indonesia (WPPNRI). Penelitian ini menggunakan metode deskriptif analitis yang menggunakan studi kepustakaan untuk menganalisis masalah-masalah yang disajikan. Dari hasil analisis dapat disimpulkan bahwa RFMos merupakan organisasi pengelola perikanan daerah di laut lepas yang bertujuan untuk mengelola dan melestarikan ikan. Selain itu, RFMos juga dapat digunakan sebagai alat bagi negara maju untuk mengendalikan laut lepas dengan membuat aturan penangkapan ikan di laut lepas.
\end{abstract}

Kata Kunci: Ikan Tuna, LPP, Perlindungan

Abstract. Tuna fish with a wide range through the EEZ sea is a type of fish whose management is a shared responsibility between countries. Therefore, the status of national fisheries management has always been monitored by the Regional Fisheries Management Bodies (RFMOs). The Ministry of Marine Affairs and Fisheries recently issued a Regulation of the Minister of Marine Affairs and Fisheries of the Republic of Indonesia No.33 of 2019 concerning the Organization and Work Procedure of the State Fisheries Management Agency for the Republic of Indonesia which is compiled and improved to increase efficiency, optimize and coordinate the implementation of the management of the State Fisheries Management area. Republic of Indonesia (WPPNRI). This research uses analytical descriptive method which uses literature study for the problems presented. From the results of the analysis, it can be denied that RFMos is a regional fisheries management organization in the high seas that aims and conserves fish. In addition, RFMos can also be used as a tool for countries moving forward to control the high seas by making fishing rules on the high seas.

Keyword: Tuna, LPP, Protection 


\section{PENDAHULUAN}

Perikanan di seluruh dunia memberikan kontribusi yang sangat penting untuk kesejahteraan manusia, menjadi dasar penyediaan bahan pangan, kesempatan kerja atau mata pencaharian, dan juga rekreasi bagi ratusan juta orang di seluruh dunia. ${ }^{1}$ Sektor perikanan juga memiliki peran dalam memenuhi kebutuhan global akan pangan dan meningkatkan kesehatan masyarakat dunia. Namun pada sisi lain, hal ini juga menyebabkan peningkatan permintaan atas produk perikanan, dimana produk perikanan menjadi salah satu yang

diperdagangkan secara internasional dan memiliki nilai jual yang tinggi. Oleh karenanya, pendekatan terintegrasi melalui pendekatan ekosistem terhadap pengelolaan perikanan menjadi sangat penting. Salah satu metode pendekatan pengelolaan perikanan adalah dengan menggunakan pendekatan EAFM (Ecosystem Approach to Fisheries Management). Penilian terhadap indikatorindikator yang terdapat pada EAFM diharapkan dapat menjadi mekanisme penilaian pengelolaan perikanan pada suatu wilayah. Adapun indikator yang menjadi dasar penilaian keberlanjutan terhadap suatu pengelolaan perikanan meliputi 6 aspek yakni sumberdaya ikan, habitat dan ekosistem perairan, teknik penangkapan ikan, sosial, ekonomi, dan kelembagaan.

Indonesia merupakan negara kepulauan yang luas wilayah perairannya mencapai 5,4 juta $\mathrm{km}^{2}$ yang memiliki keanekaragaman hayati dalam hal ini sumber daya ikan terbesar,

diantaranya dari kelompok ikan pelagis besar yaitu ikan tuna. Spesies ikan tuna antara lain seperti cakalang (skipjack), sirip kuning (yellowfin tuna), mata besar (bigeye tuna), sirip biru selatan (southern bluefin), dan tongkol. Ikan tuna adalah kelompok ikan yang beruaya jauh (highly migratory fish stocks) atau ikan yang beruaya terbatas di antara Zona Ekonomi Eksklusif (ZEE) dari satu atau lebih negara dan laut lepas (straddling fish stocks). Salah satu sifat dari ikan tuna adalah spesies ikan yang dapat berenang dalam jarak jauh yaitu dimana ikan tuna mampu melintasi batas wilayah suatu pulau atau negara.

Ikan yang bermigrasi jauh adalah ikan dengan daya jelajah yang sangat tinggi. Di antara ikan yang bermigrasi menurut UNCLOS 1982, ikan layar 112 km / jam, marlins bisa mencapai $112 \mathrm{~km} /$ jam, tuna sirip biru $70 \mathrm{~km} /$ jam, tuna sirip kuning 74 $\mathrm{km} /$ jam, hiu biru $67 \mathrm{~km} /$ jam, ikan todak 64 $\mathrm{km} / \mathrm{h}$, hiu macan $56 \mathrm{~km} \mathrm{/} \mathrm{jam.}{ }^{3}$ Tuna merupakan jenis ikan terbesar yang termasuk dalam kategori ikan yang bermigrasi jauh, menurut Appendix I UNCLOS 1982 terdapat sembilan jenis tuna dari tujuh belas jenis ikan yang bermigrasi jauh. Ikan tuna biasanya hidup berkelompok dan selalu melakukan aktivitas dengan kecepatan $27 \mathrm{~km} /$ jam sampai dengan $75 \mathrm{~km}$ / jam baik pergerakan lokal maupun jarak jauh. ${ }^{4}$ Dengan pergerakan yang begitu cepat maka jenis ikan yang bermigrasi jauh dapat dikatakan sebagai tidak terbiasa dengan batas-batas wilayah perairan suatu negara atau bermigrasi melintasi perbatasan yurisdiksi suatu negara. Kondisi seperti itu dapat menimbulkan masalah hukum. Negaranegara yang terkait dengan jenis ikan ini merasa berhak untuk menangkap ikan tersebut. Misalnya negara-negara tempat ikan bertelur, dibesarkan, dan memilih tujuan akhir menetap (hidup) merasa berhak atas ikan yang ada. Akibatnya, bisa terjadi pelanggaran kedaulatan negara oleh negara lain. Sehingga pemanfaatannya harus melibatkan seluruh pemangku kepentingan dan kelompok pemerintah di tingkat nasional dan internasional.

Pada tahun 2004, Jepang dan Taiwan mengalami penurunan dalam penangkapan ikan tuna, di mana kondisi tersebut menjadikan Indonesia sebagai negara penghasil ikan tuna di dunia. Kementerian Kelautan dan Perikanan Republik Indonesia (KKP RI) menyusun Rencana Strategis (Strategic Plan) tahun 2010 - 2014 yang bertujuan agar produksi ikan tangkap di laut meningkat sebesar $0,5 \%$ per tahun, dari produksi sebanyak 5,38 juta ton pada tahun 2010 menjadi 5,5 juta ton pada 2014. Meskipun memiliki nilai potensi ekonomi 
dan sosial yang sangat besar, namun sumber daya perikanan terkena dampak buruk akibatkegiatan eksploitasi yang berlebihan (overfishing) dan belum memperhatikan ekosistem sebagai bagian dari pengelolaan yang komprehensif untuk menjaga keberlanjutan sumber daya.

Selain itu, dalam pengelolaan perikanan sangat penting untuk mempertimbangkan dimensi sumber daya perikanan dan ekosistemnya, dimensi pemanfaatan sumber daya perikanan untuk kepentingan sosial ekonomi masyarakat, dan dimensi kebijakan perikanan itu sendiri. ${ }^{7}$ Disamping itu, untuk mewujudkan pengelolaan tersebut diperlukan perencanaan kebijakan terkait dengan komitmen pengambilan keputusan, mekanisme koordinasi, dan hubungan antar regulasi. Pengelolaan perikanan secara umum dan pengelolaan perikanan tuna secara khusus sangat penting dilakukan di berbagai wilayah di dunia dengan pertimbangan sebagai berikut:

Pemenuhan kebutuhan protein: selain melakukan pengaturan penangkapan ikan, upaya lainnya yang telah dilakukan untuk menjaga agar stabilitas protein tetap terjaga adalah melalui pengelolaan sumber daya ikan secara baik, arif, dan bijaksana dengan cara mengadopsi regulasi dan bergabung pada Regional Fishery Management Organisations (RFMO). Pengelolaan perikanan tuna melalui RFMO diharapkan turut memberikan kontribusi dalam menjaga dan memenuhi kebutuhan pangan. Dengan menjaga standar kualitas yang tinggi, pengelolaan perikanan tuna wajib memperhatikan aspek legality, regulated and reported (LRR) bukan illegal unregulated, dan unreported (IUU). Pengelolaan perikanan tuna yang IUU dan melanggar kesepakatan RFMO akan menyebabkan produk hasil tangkapan tidak diterima oleh konsumen karena secara spesifik melanggar ekolabel sehingga dapat menghambat pemenuhan kebutuhan protein;

1. Ketergantungan terhadap sumber daya: kecenderungan mengkonsumsi ikan yang menyebabkan peningkatan permintaan untuk memenuhi kebutuhan tentu akan mengubah pola pengelolaan perikanan tuna di seluruh dunia, sehingga pengelolaan perlu dilakukan berdasarkan regulasi yang disepakati oleh negaranegara anggota RFMO;

2. Kepemilikan terhadap sumber daya ikan: sumber daya perikanan yang bersifat terbuka (open access) dapat diakses oleh hampir semua kapal dan secara tidak terbatas sehingga menyebabkan kerusakan sumber daya dan masalah ekonomi. Pengelolaan yang tidak terkontrol oleh akses kapal berakibat over eksploitasi. Oleh karena itu, pengelolaan menjadi sangat dibutuhkan untuk menjaga ritme dalam mengeksploitasi sumber daya;

3. Peningkatan eksploitasi: ikan tuna memiliki nilai komersial tinggi secara ekonomi sehingga menjadi salah satu produk primadona yang diekspor ke beberapa negara di dunia. Karena pemanfaatan tuna berada pada ambang eksploitasi penuh (fully exploited) menjadi alasan utama bagi nelayan dan pengusaha tuna untuk melakukan penangkapan ikan tuna secara intensif di alam.

United Nations Convention on the Law of the Sea (UNCLOS) tahun 1982 meminta negara-negara pantai untuk bekerjasama dalam memastikan konservasi dan pemanfaatan yang optimal untuk spesies ikan yang beruaya jauh melalui RFMO, termasuk dengan menciptakan RFMO baru seperti Inter-American Tropical Tuna Commission (IATTC), International Commission for the Conservation of Atlantic Tunas (ICCAT), Commission for the Conservation of Southern Bluefin Tuna (CCSBT), Indian Ocean Tuna Commission

IOTC), dan Western and Central Pacific Fisheries Commission (WCPFC), bertujuan untuk mengelola perikanan tuna dan memastikan persediaan ikan tuna dan mampu mendukung keberlanjutan secara maksimum. ${ }^{9}$ Berdasarkan skema untuk daftar kapal IUU dari RFMO, terdapat 355 kapal penangkap ikan milik indonesia yang 
diidentifikasi sebagai kapal IUU berdasarkan informasi dari CCSBT dan 75 kapal longline berskala besar milik Indonesia yang diidentifikasi sebagai kapal IUU berdasarkan informasi dari ICCAT. Perikanan IUU ini tentunya memiliki dampak ekonomi dan politik di Indonesia.

Melihat fenomena di atas, menjadi sangat relevan untuk mengetahui bagaimana peran lembaga pengelolaan perikanan tuna di Indonesia. Hal ini dirasa penting karena apabila Hukum Internasional telah menyediakan kerangka hukum yang cukup bagi keberlanjutan pengelolaan perikanan, maka aturan Hukum Internasional ini dapat dijadikan pedoman bagi pelaksanaan pengelolaan perikanan di tingkat nasional.

\section{PEMBAHASAN}

Argumen telah dibuat bahwa sistem pengelolaan sumber daya lokal dapat menjadi efektif, efisien dan adil dalam efek distribusinya. Namun, jika mengamati sumberdaya perikanan laut di Indonesia, terlihat jelas bahwa sistem seperti itu adalah pengecualian daripada aturan. Penguasaan lokal atas sumber daya perikanan telah didokumentasikan di beberapa bagian Sumatera, Kalimantan, Sulawesi, dan Kepulauan Maluku. Tidak ada sistem seperti itu yang telah didokumentasikan untuk Jawa atau salah satu Kepulauan Sunda Kecil. Hanya sebagian kecil dari jutaan lebih nelayan Indonesia yang memiliki suara dalam pengelolaan sumber daya yang mereka andalkan. Ini tidak berarti bahwa sistem seperti itu tidak penting. Eksploitasi sumber daya perikanan yang berlebihan merupakan masalah serius di banyak daerah di Indonesia. Pengaturan mandiri oleh mereka yang mengeksploitasi sumber daya mungkin terbukti menjadi elemen penting dalam mencapai panen perikanan berkelanjutan. Pelajaran dari sistem pengelolaan lokal yang ada mungkin terbukti berharga dalam mencapai tujuan ini. Di antara pelajaran ini adalah pengenalan kualitas dinamis dari sistem ini dan adanya tekanan yang cenderung merusak sistem tersebut.
Kecenderungan sentralisasi kebijakan pemerintah Indonesia merupakan faktor utama cenderung merongrong otoritas lembaga lokal yang bertanggung jawab atas sumber daya pengelolaan. Faktor lain yang cenderung mengikis kemampuan lokal untuk mengelola sumber daya perikanan termasuk peningkatan populasi manusia dan munculnya pasar nasional dan internasional untuk sumber daya laut yang baru berharga. ${ }^{10}$ Populasi Indonesia yang terus berkembang telah menghasilkan peningkatan permintaan ikan sementara pasar internasional untuk ikan trochus, berduri lobster, teripang, dan spesies laut lainnya telah meningkatkan taruhan ekonomi terkait dengan kontrol atas daerah penangkapan ikan dekat pantai setempat. Komersialisasi perikanan laut yang dihasilkan tidak hanya menciptakan peluang ekonomi baru bagi masyarakat lokal nelayan, seringkali menyebabkan hilangnya kendali masyarakat atas sumber daya lokal. Sementara beberapa individu lokal telah memperoleh manfaat dari transformasi ini, manfaat ini sering kali telah dimenangkan dengan mengorbankan penipisan sumber daya dan erosi sumber daya sistem alokasi berdasarkan standar lokal pemerataan distribusi.

Kebijakan

pembangunan berkelanjutan mencakup semua sektor pembangunan, termasuk di dalamnya adalah sektor perikanan. Istilah perikanan berkelanjutan (sustainable fisheries) mulai dijadikan agenda dunia pada tahun 1995 melalui perumusan konsep pembangunan perikanan berkelanjutan oleh FAO, yaitu penyusunan dokumen Code of Conduct for Responsible Fisheries (CCRF). Ketersediaan ikan dapat berlangsung terus-menerus pada tingkat yang wajar dengan mempertimbangkan ekologi, meminimalkan efek samping yang mengganggu keanekaragaman jenis ikan, dan fungsi ekosistem, serta dikelola dan dioperasikan secara adil dan bertanggung jawab, sesuai dengan hukum dan peraturan lokal, nasional, dan internasional untuk memenuhi kebutuhan generasi sekarang dan generasi masa depan. 
Menurut Pasal 61-67 UNCLOS, ketentuan mengenai ikan yang bermigrasi jauh dimuat dalam Bab V: Zona Ekonomi Eksklusif. Dalam bab ini, Pasal 61 secara jelas mengamanatkan kerjasama antara negara pantai dan organisasi internasional untuk melakukan tindakan konservasi dan pengelolaan perikanan berdasarkan bukti ilmiah. ${ }^{11}$ Ketika pasokan ikan jenis yang sama ditemukan di dua atau lebih negara pantai baik di ZEE dan di luar, negaranegara ini harus berkoordinasi melalui organisasi regional untuk mengembangkan kesepakatan untuk tindakan yang diperlukan, seperti konservasi persediaan (Pasal 63). Khusus untuk ikan yang bermigrasi jauh, negara pantai dan negara lain yang warganya menggunakan jenis ikan yang bermigrasi jauh di wilayahnya harus bekerja sama secara langsung atau melalui organisasi internasional (Pasal 64 UNCLOS 1982). Rezim Laut Tinggi diatur dalam Bab VII (Pasal 86-120). Pengelolaan dan konservasi sumber daya di laut lepas dapat dilakukan secara sepihak atau kerjasama antar negara (Pasal 117). Negara harus mengatur pengelolaan dan konservasi, dan jika memungkinkan, dengan membentuk organisasi pengelolaan perikanan regional di berbagai daerah yang memiliki aturan sendiri untuk mengelola kegiatan perikanan (Pasal 118).

Pasal 87 UNCLOS mengatur bahwa setiap negara mempunyai hak untuk memanfaatkan laut bebas dan memiliki kebebasan yang diakui secara universal. Salah satu hak atas pemanfaatan laut adalah kebebasan untuk menangkap ikan (freedom of fishing) yang harus dilakukan oleh setiap Negara. Khusus untuk hak menangkap ikan, UNCLOS mempertegas kembali dalam Pasal 116 mengenai hak dari suatu negara untuk mengirimkan armada perikanan nasionalnya ke laut bebas. Namun, bersamaan dengan ketentuan tersebut, langkah-langkah konservasi dari harus dilakukan secara unilateral maupun bekerjasama dengan Negara lain. Dorongan diadakannya kerjasama antara Negaranegara yang memanfaatkan sumber daya ikan tuna ditekankan dalam Pasal 118 UNCLOS, dimana Negara-negara harus mengatur pengelolaan dan konservasi, bekerjasama untuk menetapkan organisasi perikanan sub-regional atau regional. ${ }^{12}$

Indonesia sebagai salah satu negara produsen tuna memiliki kepentingan dalam menjaga keberlanjutan sumber dayanya. Oleh karena itu, sebagai bentuk dari implementasi Pasal 118 UNCLOS tersebut Indonesia membutuhkan kerjasama regional dan internasional. Sebagai cerminan politik hukum Indonesia untuk terlibat dalam RFMO dapat dilihat dalam ketentuan pasal 10 ayat (2) UndangUndang No. 31 Tahun 2004 tentang Perikanan sebagaimana telah diubah dengan Undang-Undang No. 45 Tahun 2009 ("UU Perikanan") yang menyebutkan bahwa pemerintah ikut serta secara aktif dalam keanggotaan badan/lembaga/organisasi regional dan internasional dalam rangka kerja sama pengelolaan perikanan regional dan internasional. Selain itu, Pasal 11 ayat (2) huruf f Undang-Undang No.32 Tahun 2014 tentang Kelautan turut mengamanatkan kewajiban Pemerintah untuk berpartisipasi dalam pengelolaan perikanan yaitu terlibat dalam RFMO sebagai forum pengelolaan perikanan regional dan internasional, seperti Komisi Perikanan Pasifik Barat dan Tengah (Western and Central Pacific Fisheries Commission (WCPFC)), Komisi Tuna 
Samudra Hindia (Indian Ocean Tuna Commision (IOTC)), dan Komisi untuk Konservasi Tuna Sirip Biru Selatan (Commission for the Conservation of Southern Bluefin Tuna (CCSBT)). UU Perikanan sebagai bentuk kepentingan dan kepedulian Indonesia untuk menjaga serta mengelola sumber daya perikanan yang dibuktikan menjadi anggota dari RFMOs sehingga dapat berperan serta dalam pengelolaan dan konservasi sumber daya perikanan di laut lepas.

Salah satu tujuan pembangunan perikanan sebagaimana tertuang dalam Rencana Strategis Kementerian Kelautan dan Perikanan 2010-2014 adalah untuk mengelola perikanan secara berkelanjutan. Kontrol masukan telah dipraktekkan sejak awal 1970-an dan telah dilaksanakan melalui sistem perizinan di mana Pemerintah Pusat (melalui Kementerian Kelautan dan Perikanan "MOMAF") memberikan izin penangkapan ikan untuk kapal yang berukuran lebih dari 30 GT, Pemerintah Provinsi untuk kapal 20-30 GT dan Pemerintah Kabupaten untuk kapal 520 GT. Rezim akses terbuka masih berlaku untuk kapal penangkap ikan dengan berat kurang dari 30 GT di bawah yurisdiksi pemerintah provinsi dan kabupaten. Tindakan teknis yang diterapkan berupa (i) ukuran mata jaring minimum untuk ujung pukat jaring pukat-hela (trawl) udang (1 inci untuk pukat-hela (trawl) udang dan 5 $\mathrm{cm}$ untuk pukat ikan), (ii) ukuran mata jaring minimum untuk pukat cincin, (iii) maksimum panjang jaring insang $(10 \mathrm{~km})$, dan (iv) pembebanan jarak minimum antar rumpon minimal 10 mil laut. Tidak ada pengendalian keluaran yang dipraktikkan di Indonesia. Pengecualian adalah pengelolaan perikanan tuna sirip biru selatan dimana Indonesia adalah Negara sebagai anggota Komisi Konservasi Tuna Sirip Biru Selatan (CCSBT) telah menerima kontrol keluaran. Insentif ekonomi telah diberikan, seperti subsidi bahan bakar untuk kapal berukuran kurang dari 30 GT dan program kredit untuk perikanan skala kecil. Indonesia tidak banyak menerima bantuan luar negeri untuk pengembangan perikanan. Pada saat penulisan, tiga proyek yang cukup besar sedang dilaksanakan. Yang pertama adalah "Proyek Pengelolaan dan Rehabilitasi Terumbu Karang" (COREMAP) yang didukung oleh Fasilitas Lingkungan Global (GEF), Bank Pembangunan Asia (ADB), dan Bank Dunia. Proyek besar kedua Coral Triangle Initiative - bersifat regional. Itu dilakukan di Indonesia, Malaysia, Filipina, Papua Nugini, Kepulauan Solomon dan Timor Leste. Beberapa donor nasional (ADB, USAID, AUSAID, GEF) mendukung proyek dengan mengalokasikan dana untuk LSM yang berpartisipasi. Terakhir, Indonesia telah berpartisipasi dalam proyek regional baru-baru ini, "Ekosistem Laut Besar Teluk Benggala", yang secara finansial didukung oleh GEF. FAO membantu negara dalam proyek pasca tsunami, khususnya di Aceh dan Nias.

Selain itu, Pemerintah Indonesia meratifikasi Agreement for the Implementation of the Provisions of the United Nations Convention on the Law of the Sea of 10 December 1982 relating to the Conservation and Management of Straddling Fish Stocks (United Nation Implementing Agreement (UNIA) tahun 1995 dalam Undang-Undang No.21 Tahun 2009 ("UU UNIA") sebagai bentuk komitmen Indonesia dalam rangka pengelolaan ikan tuna secara berkelanjutan dengan berbagai negara di dunia. Selanjutnya, UU Perikanan turut mengamanatkan agar pemerintah dapat sepenuhnya mampu mengantisipasi perkembangan teknologi dan kebutuhan hukum dalam rangka pengelolaan dan pemanfaatan potensi sumber daya ikan. ${ }^{13}$

Berdasarkan penjelasan UU UNIA, manfaat yang ingin dicapai ialah sebagai berikut:

4. Memantapkan kebijakan Pemerintah Indonesia dalam memberantas IUU fishing

5. Mendapat informasi perikanan secara akurat

6. Mendapatkan alokasi sumber daya perikanan untuk jenis ikan beruaya 
dan beruaya terbatas

7. Memperoleh bantuan dan perlakuan khusus sebagai negara berkembang 
RFMO sebagai organisasi pengelolaan perikanan regional menjadi sangat berperan penting dalam pemanfaatan sumber daya ikan tuna melalui pengelolaan yang berorientasi pada kepentingan jangka panjang dan bertanggung jawab untuk menjawab tantangan pembangunan perikanan yang berkelanjutan (sustainable fisheries development). RFMO melalui UNCLOS 1982 mengamanatkan pengelolaan dan pemanfaatan sumber daya ikan tuna pada ZEE yang tertuang pada Bab V Pasal 61-67 UNCLOS, kerja sama negara-negara dalam konservasi dan pengelolaan sumber daya hayati di laut lepas yang tertuang pada Bab VII Pasal 118, pengelolaan perikanan pada laut tertutup atau setengah tertutup tertuang Pada Bab IX Pasal 123. Kehadiran RFMO sebagai organisasi regional diharapkan mampu menyediakan bahan pangan, kesempatan kerja, perdagangan, kesejahteraan ekonomi bagi pelaku perikanan serta penduduk dunia yang terus mengalami peningkatan. RFMO adalah organisasi internasional yang bergerak di bidang perikanan yang beranggotakan negara pantai yang memiliki sumber daya ikan yang perlu dilestarikan. Anggota RFMO adalah negara dan organisasi yang memiliki kepentingan di bidang sumber daya ikan. Secara umum keanggotaannya merupakan contracting party dimana negara anggotanya tetap berada dalam koridor hukum positif apabila terjadi permasalahan atau perselisihan di bidang perikanan di wilayahnya, namun negara anggota RFMO mempunyai kewajiban yang harus dipenuhi terhadap organisasi tersebut. $^{14}$ Setidaknya ada 8 (delapan) RFMO di dunia, termasuk The Commission for the Conservation of Antarctic Marine Living Resources (CCAMLR), The General Fisheries Commission for the Mediterranean (GFCM), The North East Atlantic Fisheries Commission (NEAFC), The North Pacific Fisheries Commission (NPFC), Organisasi Perikanan Atlantik Barat Laut (NAFO), Organisasi Perikanan Atlantik Tenggara (SEAFO), Perjanjian
Perikanan Samudra Hindia Selatan (SIOFA), dan Organisasi Manajemen Perikanan Regional Pasifik Selatan (SPRFMO). ${ }^{15}$

Selengkapnya tentang teks sumber iniDiperlukan teks sumber untuk mendapatkan informasi terjemahan tambahan

Dalam keanggotaannya dalam RFMO, Indonesia tentunya berkewajiban untuk: ${ }^{16}$

1. Mematuhi semua resolusi dan conservation management measures (CMM) yang sudah diadopsi oleh masing-masing RFMOs;

2. Mengadopsi semua resolusi dan conservation management measures (CMM) yang aplikatif ke dalam legislasi nasional;

3. Membuat laporan tahunan;

4. Melaporkan data dan informasi yang dipersyaratkan oleh resolusi seperti pendataan Ecologically Related Species (ERS);

5. Mendaftarkan kapal-kapal yang menangkap tuna dan spesies seperti tuna ke RFMOs terkait;

6. Menghadiri pertemuan tahunan, compliance, dan working group yang relevan.

Keuntungan yang diperoleh dengan bergabung RFMO dalam pengelolaan perikanan tuna antara lain:

a. Penghematan waktu dan biaya dalam kerja sama penelitian dan pengumpulan data perikanan, pemanfaatan secara optimal jumlah tangkapan yang diperbolehkan (total allowable catch, TAC). penegakkan hukum serta pengelolaan dan konservasi sumber daya ikan yang banyak membutuhkan tenaga ahli, Indonesia tidak dianggap melakukan penangkapan ilegal di perairan laut lokasi RFMO, dan mendapatkan 
jaminan akses pemasaran tuna di pasaran internasional dan diterimanya ekspor tuna Indonesia ke negara tujuan ekspor.

b. Penambahan kapasitas usaha produksi penangkapan ikan di wilayah konvensi.

c. Kerja sama dalam pengelolaan dan verifikasi semua data dan informasi terkait penangkapan

d. Bekerja sama dengan respons yang cepat dalam mengembangkan penyelidikan IUU Fishing sehingga bisa menjadi LRR Fishing.

e. Kerja sama dalam pemonitoran, kontrol, dan pengawasan.

f. Kerja sama dalam membuat kebijakan dan prosedur yang cocok

g. Produk tuna Indonesia yang ditangkap di perairan wilayah RFMO berstatus legal di pasar regional dan internasional

h. Kerja sama dalam menyalurkan kemampuan dan teknologi

i. Indonesia memiliki hak suara dalam pengambilan keputusan pada setiap sidang komisi dan terpenuhinya kewajiban Indonesia dalam rangka implementasi UNCLOS 1982.

j. Program pencitraan diri dalam meningkatkan posisi tawar sebagai sebuah negara yang bertanggung jawab dalam mewujudkan perikanan yang berkelanjutan secara global

k. Indonesia berhak mendapatkan kuota penangkapan tuna.

1. Memfasilitasi masyarakat dalam mengakses sumber daya ikan di laut lepas.

UNCLOS mengatur pengelolaan dan konservasi sumber daya perikanan tetapi tidak mengatur secara detail mengenai hak dan kewajiban Negara yang memanfaatkan ikan yang beruaya terbatas dan ikan yang beruaya jauh, di mana hal ini dapat menimbulkan potensi sengketa antara negara pantai dengan negara pantai atau antara negara pantai dengan negara penangkap ikan jarak jauh sehubungan dengan eksploitasi sumber daya secara berlebihan. Amanat Agenda 21 pada konferensi perserikatan bangsa-bangsa tentang lingkungan hidup dan pembangunan pada 1992 yaitu mengharuskan negara-negara mengambil langkah yang efektif melalui kerja sama global untuk menjamin perikanan di laut lepas dapat dikelola sesuai dengan ketentuan UNCLOS 1982. Namun, amanat tersebut tidak ditindaklanjuti dengan dikeluarkannya Resolusi Majelis Umum PBB No.47/192 yang menghendaki adanya konferensi tentang jenis ikan yang beruaya terbatas dan jenis ikan yang beruaya jauh.

Mandat untuk ikut dalam RFMO bagi negara pantai dan negara-negara yang melakukan penangkapan ikan secara tegas diatur dalam Pasal 8 ayat 1 UNIA, di mana negara-negara yang memiliki hak akses untuk memanfaatkan jenis-jenis ikan yang beruaya terbatas dan beruaya jauh di laut lepas adalah negara-negara yang menjadi anggota dari organisasi perikanan subregional atau regional dan bekerjasama dalam penerapan ketentuan konservasi dan pengelolaannya. Negara yang telah menjadi anggota organisasi perikanan regional disyaratkan untuk menyetujui jumlah tangkapan yang diperbolehkan dan levels of fishing effort, serta telah mempersiapkan mekanisme kerjasama dalam kegiatan monitoring control and surveillance dan penegakan hukumnya secara efektif. Ketentuan tersebut juga berlaku bagi negara yang tidak menjadi anggota suatu organisasi perikanan sub regional dan regional untuk bekerjasama dalam upaya konservasi dan pengelolaan jenis-jenis ikan yang beruaya terbatas dan beruaya jauh sesuai dengan ketentuan UNCLOS 1982.

Sejak tahun 2015 Pemerintah Indonesia telah menetapkan "Tuna Fisheries Management Plan" melalui Keputusan Menteri Kelautan dan Perikanan Republik Indonesia Nomor 107/KEPMENKP/2015 tentang Rencana Pengelolaan Perikanan Tuna, Cakalang dan Tongkol sebagai referensi dasar pengelolaan perikanan tuna di Indonesia. Selanjutnya 
sejalan dengan Kebijakan Perikanan Nasional, Indonesia juga terus menerus berupaya untuk meningkatkan kepatuhan agar semua produk perikanan Indonesia termasuk komoditi tuna bukan berasal dari khusus (Satgas 115), keterlibatan Indonesia sebagai champion partner Global Record of Fishing Vessels, integrasi data VMS dengan Global Fishing Watch yang telah memberikan dampak positif terhadap upaya Indonesia untuk turut menjamin keberlanjutan usaha perikanan tuna dunia. ${ }^{17}$ Upaya dalam membasmi IUU Fishing juga dilakukan dengan mendorong entitas dunia untuk menyatakan IUU Fishing sebagai transnational organized crime (TOC). pemerintah Republik Indonesia telah meratifikasi Port State Measure Agreement (PSMA) melalui Peraturan Presiden Nomor 43 tahun 2016. Saat ini, KKP sedang membuat Standar Operasional Prosedur (SOP) untuk penerapan PSMA tersebut sebagai langkah awal otoritas pelabuhan perikanan dalam memperkuat pengawasan, mencegah dan membasmi IUU fishing. Pemerintah Indonesia juga berkomitmen untuk mengintegrasikan semua database dan sistem pemantauan perikanan tuna di Indonesia dalam meningkatkan validitas dan akurasi data dari waktu ke waktu sebagai bagian dari meningkatkan kepatuhan Indonesia terhadap Tuna Management and Conservation Measures RFMO. Dengan demikian, tindakan nyata telah diambil pemerintah Indonesia dalam berpartisipasi untuk mewujudkan pengelolaan perikanan tuna dunia yang berkelanjutan.

Hal ini berakibat serius bagi Indonesia, karena dengan tidak menjadi anggota, Indonesia dinilai tidak berniat baik untuk memperhatikan kelestarian sumberdaya tuna di wilayah tersebut. Dengan kondisi ilegal, hasil produksi tuna Indonesia akan digolongkan tidak dilaporkan. Dalam hal ini, dapat dikatakan bahwa negara-negara maju telah melaksanakan hegemoni di laut lepas yang merupakan neo kolonialisme atau kolonialisme secara halus. Menurut Adi Sulistiyono $^{20}$, telah terjadi tarikan pada sistem hukum di Indonesia yang berdampak praktek-praktek IUU Fishing. KKP telah dan terus berupaya serius dalam memberantas IUU Fishing. Upaya-upaya tersebut antara lain pembentukan satuan tugas

pada partisipasi Indonesia menjadi anggota RFMOs. Tarikan ini berarti terdapat hukum atau politik internasional yang mempengaruhi partisipasi suatu negara dalam perjanjian internasional. ${ }^{21}$ Terkait pembentukan RFMO, negara maju menggunakan pelestarian sumber daya perikanan di laut lepas sebagai alasan untuk mewujudkan kepentingannya. Bagi CCSBT, Indonesia merupakan negara yang memiliki kedudukan penting karena terdapat tempat pemijahan SBT di wilayah Indonesia. Selain itu, sebagai salah satu negara yang memanfaatkan SBT untuk kepentingan nasional, Indonesia didorong oleh negaranegara anggota CCSBT untuk dapat mendukung upaya pelestarian dan pemanfaatan SBT.

Selain itu, Kementerian Kelautan dan Perikanan belakangan ini mengeluarkan Peraturan Menteri Kelautan dan Perikanan Republik Indonesia No.33 Tahun 2019 tentang Organisasi dan Tata Kerja Lembaga Pengelola Perikanan di Wilayah Pengelolaan Perikanan Negara Republik Indonesia disusun dan ditetapkan untuk peningkatan efisiensi, optimalisasi, dan koordinasi pelaksanaan pengelolaan perikanan di Wilayah Pengelolaan Perikanan Negara Republik Indonesia (WPPNRI). Peraturan ini mengatur mengenai Komisi Pengelola Perikanan yang bertugas melakukan perumusan masukan dalam penyusunan, pelaksanaan, dan evaluasi pelaksanaan RPP, serta rekomendasi penyusunan kebijakan pengelolaan perikanan berkelanjutan di WPPNRI.

\section{KESIMPULAN}

Ikan Tuna dengan daya jelajah luas melewati laut ZEE menjadi jenis ikan yang pengelolaannya menjadi tanggung jawab bersama antarnegara.Oleh karena itu, status pengelolaan perikanan tuna nasional selalu menjadi pantauan dari Lembaga Pengelolaan 
Perikanan Regional (Regional Fisheries Management Bodies - RFMOs). RFMOs mempunyai mandat untuk pengaturan pengelolaan tuna secara global/Internasional. Dalam pengelolaan perikanan tuna, Indonesia sudah turut bergabung dengan CCSBT, IOTC, dan WCPFC, di mana Indonesia mengadopsi ketentuan-ketentuan RFMO dalam peraturan perundangundangan nasional. Melalui keanggotaannya, ndonesia perlu melaksanakan secara penuh seluruh regulasi yang dikeluarkan oleh RFMO untuk mencegah terjadinya tindakan yang dikategorikan dalam IUU fishing pada masing-masing RFMO. Selain RFMO, Pemerintah harus mengimplementasikan pembentukan Komisi Pengelola Perikanan sebagai lembaga pengelola perikanan dari sisi nasional.

Dari hasil analisis dapat disimpulkan bahwa RFMos merupakan organisasi pengelola perikanan daerah di laut lepas yang bertujuan untuk mengelola dan melestarikan ikan. Selain itu, RFMos juga dapat digunakan sebagai alat bagi negara maju untuk mengendalikan laut lepas dengan membuat aturan penangkapan ikan di laut lepas. Keikutsertaan RFMO Indonesia dipengaruhi oleh hukum dan globalisasi yang berkembang di bidang perikanan, seperti saat Indonesia belum menjadi anggota RFMO, ada tekanan dari negara maju dengan pengenaan sanksi embargo ekspor tuna Indonesia karena produk perikanan Indonesia dikategorikan dalam praktik IUU Fishing. Di sisi lain, terdapat berbagai keuntungan bagi Indonesia menjadi Anggota RFM, antara lain menghemat waktu dan biaya dengan kesempatan untuk kolaborasi penelitian dan pengumpulan data perikanan, memanfaatkan total allowable catch (TAC), melakukan pemantauan, pengendalian dan pengawasan (MCS), penegakan hukum, pengelolaan dan konservasi ikan. sumber daya ikan yang membutuhkan banyak tenaga ahli serta mendapatkan kuota penangkapan dan jaminan akses pemasaran tuna di pasarinternasional.

\section{DAFTAR PUSTAKA}

A. Dwiponggo, Pemanfaatan Dan Pengelolaan Optimal Perikanan Laut Dalam Pembangunan Jangka Panjang (PJP) Tahap II, Jakarta: Balitbang Pertanian Pusat Penelitian dan Pengembangan Perikanan kerjasama dengan USAID/FRDF, 1991.

Adi Sulistiyono dan Muhammad Rustamaji, Hukum Ekonomi Sebagai Panglima, Sidoarjo: Masmedia Buana Pustaka, 2009.

Ahmad Solikhin, Neo Koloniaslisasi di Laut Lepas, Sinar Harapan 11 April 2005.

Anastasia Telesetsky, "U.S. Seafood Traceability as Food Law and the Future of Marine Fisheries, Environmental Law", Vol. 47, No. 3 (Summer 2017.

Anthony T. Charles, Sustainable Fishery Systems, (Inggris: Blackwell Science Ltd, 2001).

Aryuni Yuliantiningsih, "The Participation of Indonesia in Regional Fisheries Management Organizations (Rfmos): The Legal and Globalization Perspectives", Jurnal Ilmu Hukum Unifikasi, Vol. 6 No. 2, 2018.

Conner Bailey dan Charles Zerner, Community Based Fisheries Management Institutions in Indonesia, New Zealand: Marecentre, 2017.

Erni Widjajanti, Pengelolaan Perikanan Tuna Indonesia dan Peran Kerjasama Indonesia dalam RFMO, Kementerian Kelautan dan Perikanan, disampaikan pada Seminar Nasional Hukum Laut, 2013, Universitas Sebelas Maret, Surakarta

Indonesian Journal of International Law Vol.2, No.3, 2005/

Kavern L. Cochrane dan S.M. Garcia, eds., A Fishery Manager's Guidebook, 2nd Edition, (FAO dan Wiley-Blackwell Publishers, 2009.

Khairunnisah, N. A., Sulhaini, S., \& Mulyono, L. E. H. (2020). The Effect of Halal Destination Image, Travel Motivation and Marine Tourism as Branding Icons on Tourists' Decisions 
to Revisit. International Journal of Multicultural and Multireligious Understanding, 7(11), 40-49.

Krisna Fery Rahmantya, Anggie Destiti Asianto, dan Dadang Wibowo, Analisis Data Pokok Kelautan Dan Perikanan 2015, Jakarta: Pusat Data, Statistik dan Informasi Kementerian Kelautan dan Perikanan, 2015.

Lischewski, Conservation and management of transnational tuna fisheries. Lowa, USA: Willey-Blackwell; 2010.

Melda Kamil Ariadno, Kepentingan Indonesia Dalam Pengelolaan Perikanan Laut Bebas,

Michael M. Sissenwine, Pamela M. Mace, dan Hans J. Lassen, Preventing Overfishing: Evolving Approaches and Emerging Challenges, (ICES J. Mar. Sci.,2014), 71:2.

Wayan Kantun, Pengeloaan Perikanan Tuna, (Yogyakarta: Gadjah Mada University Press, 2018.

Wayan Kantun, Pengelolaan Perikanan Tuna, (Yogyakarta: Gadjah Mada University Press, 2018). 